\section{MME. Victor-Noury Foundation}

René Bourret (2,500 francs), for his work on the snakes of Indo-China; Elisabeth Jérémine (2,500 francs), for researches in petrography; Robert Didier and Paul Rode (2,000 francs), for their work on the mammals of France; Jules Guiart $(\mathbf{2 , 0 0 0}$ francs), for his book on the parasitic cestodes obtained during the voyages of Prince Albert of Monaco, 18861913 ; Jacques Pochon (2,000 franes), for his work on the role of a cellulolytic bacterium of the paunch in the digestion of cellulose in ruminants; Henri Stehlé $(2,000$ francs), for starting his work on the flora of Guadeloupe; André Thomas (2,000 francs), for work in experimental eytology ; Voldemar Vilter $(2,000$ francs $)$, for his work on the formation of the feather and its histological mechanism; Elisabeth Sylvain-David (2,000 francs), for the publication of a memoir on the Foraminifera.

\section{General Foundations}

The Pierre Lafitte Foundation to Robert Burean, for his researches on the origin of atmospherics in wireless telegraphy and on the use of electro-magnetic waves for recording observations made in captive balloons; the Millet-Ronssin Foundation between René Herpin (4,000 francs), for fitting up his laboratory of marine zoology, Fernand Obaton $(3,000)$ francs), for his cinematographic studies of the movements of plants and the organization of a research centre of this nature at the Sorbonne, and Nicholas Théobald (3,000 franes), for his work on fossil insects.

\section{THE VILLEMOT Foundation}

Aimé Cotton (40,000 francs), for his researches at Bellevue with tho large electro-magnet of the Academy ; Pierre Augustin Dangeard (10,000 franes), for his botanical studies; Roger Heim $(12,000$ francs), for the study of the cryptogam material collected by him in Madagascar and the publication of the results; Gaston Julia (5,000 francs), for the mathematical circle which meets at the Henri Poincaré Institute for the study of current mathe. matical questions; Laboratoire central d'électricité (10,000 franes), for the purchase of apparatus for researches on the determination of the ohm in absolute measure with high precision; Raoul Lecoq (10,000 francs), for his work on the study of vitamins in unbalanced food regimes; Père Lejay $(10,000$ franes), for work on solar phenomena at the Zi-KaWei Observatory; Pierre Lesage (6,000 francs), for his rescarches on heredity in plants of the acquired physiological character, precocity; Berbard Lyot (30,000 francs), for his studies on the solar corona; Charles Mauguin (20,000 franes), for acquiring apparatus designed for the analysis of the crystalline structures of minerals; Jean Piveteau $(10,000$ francs), for resuming excavations in the celebrated Perrier deposit of Tertiary mammals; Hyacinthe Vincent (12,000 francs), for work relating to the etiology and pathogeny of certain infectious diseases.

The Charles Frémont Foundation to Jean Feytaud, for his researches on noxious insects and the organization of clefensive measures against these enemies.

\section{Special Foundations}

The Lannelongue Foundation to Mme. Gabriel Cusco ; the Hélène Helbronner-Fould Prize to Mme. Marie Phisalix, for her work on snake poisons; the Girbal-Baral Foundation to Mlle. Yvette Cauchois (10,000 francs), for her studies on the spectrography of the X-rays, and Roger Gautheret 10,000 francs), for his studies on the culture of plant tissues.

\title{
Air Resistance of Passenger Trains
}

$\mathrm{I}^{\mathrm{N}}$ $\mathrm{N}$ a paper read before the Institution of Mechanical Engineers on November 27, Mr. F. C. Johansen describes the results of experiments on the air resistance of passenger trains produced by modifying the shape and the smoothness of their surfaces, originally of L.M.S. pattern, in two different ways. In the first way, there was no general change in the external form of the coaches, but in the second way all coaches have smoothed bodies and faired under-carriages. The modifications introduced involved no marked alteration from the conventional appearance except for fairings on the engine, tender and the tail end of the last coach, the object being to show what reductions in air resistance could be achieved without any radical degree of stream-lining.

In the first way, the reduction of the longitudinal force was of the order of 20 per cent and decreases with the increase of the length of the train, since the reduction is mainly due to the locomotive and the first coach. In the second way, the reduction of the longitudinal force was much larger, being of the order of 50 per cent, the more effective lining being due to the all-smooth coaches. In the ideal train the corresponding reduction of the force would be about
75 per cent. The experimental results lead to the following recommendations and conclusions.

The air resistance of a train of conventional British type is equivalent to about $0.0016 \mathrm{~V}^{2} \mathrm{lb}$. per ton of train weight, where $V$ is the speed in still air in miles per hour. The air resistance can be reduced by 50 per cent without drastic departure from conventional design and by 75 per cent by ideal stream-lining. With speeds of 100 m.p.h., the corresponding fuel economy would be about $£ 1$ per hour.

It was found that the air resistance was augmented by side winds, this effect being mainly due to frontal pressure on exposed surfaces. Curiously enough, the worst natural wind is not directly ahead but ranges from $30^{\circ}$ to $60^{\circ}$ on either side of this direction. Stream-lining measures are more effective in side winds than in direct winds. The gaps between the coach bodies of an ordinary train account for very little of the total air resistance. A surprisingly large proportion of the air resistance of a coach is contributed by the bogies and under carriage structure. A fair shape at the tail end of a train reduces air resist. ance to an extent which is more marked the more complete the stream-lining. 
The full benefit of measures to reduce air resistance can be realized only if the locomotive and the coaches are all stream-lined. The final conclusion the author arrives at is that the ideal stream-lined train is a continuous cylindrical body with well-rounded ends, having a polished surface free from external fittings and irregularities. A tubular surface, incorporating a stressed skin of sheet metal, would be very suitable.

\section{Science News a Century Ago \\ The Polarization of Heat}

WHEN Whewell was publishing his "History of the Inductive Sciences", Forbes wrote to him on January 31, 1837 : "I feel gratified by the prominent place you have given to my experiments as bearing upon the theory of Heat. . . . But I must mention for yourself, if not for your book, that the discovery of the polarization of heat was not the necessary consequence of applying the thermo-multiplier to the investigation, which would have been a poor achievement, seeing it was another man's invention; but that Melloni had first applied the instrument to the tourmaline question, and answered in the negative (Ann. de Chemie, vol. 55) ; then Nobili, the inventor, attempted to repeat Berard's experiment with the most approved piles, and with results quite null (Bib. Universelle). So that I conclude that, when I published my experiments, the question of polarization was negatively answered by persons operating with every advantage which I possessed, and indeed seemed to be set at rest. My discovery was the application of mica as a polarizing substance, first by transmission, then by reflection; and $\mathrm{I}$ have shown that repeating Nobili's experiment-the same as Berard's and Powell's-the quantity of heat reflected from glass is so excessively minute that the errors might well equal the total effect. I think you have not mentioned total reflection and circular polarization.

"As to simple reflection, Melloni should be mentioned alone, but I claim double refraction."

\section{The Zoological Society}

Aт a meeting of the Zoological Society held on February 2, 1837, the Rev. John Barlow being in the chair, it was stated that the receipts for the preceding month had been $£ 2,14612 s$. $2 d$. and the expenditure $£ 1,0196 s$. $3 d$. The number of visitors to the menagerie was 1.666 , from whom $£ 4214 s$. was received, and the number of visitors to the museum 219, from whom £4 1s. was received. It was also stated that $\mathrm{Mr}$. Yarrell had agreed to act as secretary without emolument, provided an assistant secretary was appointed, which the council had taken steps to do. The number of mammalia in the menagerie was 294 , the number of birds 693 and the number of reptiles 27 .

\section{Dr. John Latham (I 740-1837)}

Dr. John LathaM, an eminent ornithologist and archæologist, and one of the many celebrated truants of medicine, who died on February 4, 1837, was born in 1740 at Eltham in Kent, the son of a surgeon. He was educated at Merchant Taylors School and studied medicine under John Hunter. He practised for many years at Dartford, where he acquired a considerable fortune which enabled him to retire in 1796 to Romsey and devote all his energies to the study of archæology and ornithology. He was elected
F.S.A. on December 15, 1774, and F.R.S. on May 25, 1775 , and took a leading part in the foundation of the Linnean Society in 1788. He was the author of a "Synopsis of Birds" published in 1785, to which he added supplements in 1787 and 1802 , and in 1790 brought out an abstract of this work entitled "Index Ornithologicus". Owing to financial losses, he was compelled to sell a great part of his library and museum, but with a rare courage, at the age of eighty-one years, he attempted to restore his fortune by an enlarged edition of his "Synopsis" entitled "A General History of Birds" which appeared between 1821 and 1828 in eleven volumes at Winchester, to which he had moved in 1820. He also took part in the revision of the secund edition of Pennant's "Indian Zoolngy" published in 1793, and contributed several papers to the Philosophical Transactions, Transactions of the Linnean Society and Archoeologia.

The subject of this note must not be confused, as was done in his obituary notice in the Gentleman's Magazine of July 1837, with another Dr. John Latham, Harveian orator in 1794 and president of the Royal College of Physicians in 1813-20.

\section{Baron Desgenettes ( $1762-1837$ )}

FEBRUARY 3 marks the centenary of the death of one of the most eminent medical men in Napoleon's army, Baron Réné Nicolas Dufriche Desgenettes. $\mathrm{He}$ was born at Alençon on February 23, 1762, and after studying medicine at Montpellier and Paris, he qualified at Montpellier in $\mathbf{1 7 8 9}$ with a Latin thesis on the lymphatics. The next two years he spent at Montpellier, and then returned to Paris, where he enjoyed the society of some of the most illustrious savants of the time, such as Pelletan, Tenon, Sabatier Condorcet, Vicq D'Azyr and Louis. On the advice of the last two, he joined the army, where in 1794 he first made the acquaintance of Napoleon. Two years later he was appointed physician and lecturer to the recently established Val-de-Grâce Military Hospital and Medical School, where he published several works on education and the treatment of war diseases, and took an active part in the foundation of two medical societies.

The next step in Desgenettes' career was his appointment by Napoleon as principal medical officer in the Egyptian and Syrian campaigns, in which he distinguished himself by his heroism and devotion to the sick and wounded. In 1802 he was made head of the Val-de-Grâce Hospital and shortly afterwards Inspector General of the Health Service of the French army. In 1805 he was sent to Spain to study the epidemic which was ravaging Cadiz, Malaga and Alicante. After taking part in the campaign in Prussia and Poland, he was made prisoner by the Russians, but was released by the Czar in gratitude for his care of the Russian wounded. At the battle of Waterloo he served as chief medical officer of the army and of the Imperial Guard. In 1822, owing to the sweeping changes made by the Frassinous régime, he was ousted from the chair of hygiene to which he had been appointed by the Directory, but was restored to it in 1830 .

Desgenettes belonged to several learned societies, including the Paris Academy of Sciences, and was one of the first members of the Paris Academy of Medicine founded in 1820 . He was a copious writer, his chief works being "Notes on the History of the Army in Italy" (1797), "The Medical History of the Army in the East (1802) and "Essays on Medical Biography and Bibliography" (1825). 